\title{
Relative importance of inoculum sources of Guignardia citricarpa on the citrus black spot epidemic in Brazil
}

\author{
Marcel B. Spósito ${ }^{\mathrm{a}, 1}$, Lilian Amorim ${ }^{\mathrm{b}, *}$, Renato B. Bassanezi ${ }^{\mathrm{a}}$, Pedro T. Yamamoto ${ }^{\mathrm{a}}$, Marcos R. Felippe ${ }^{\mathrm{a}}$, \\ Ana B.C. Czermainski ${ }^{\mathrm{c}}$ \\ a Departamento Científico, Fundecitrus, CP 391, 14801-970, Araraquara, Brazil \\ ${ }^{\mathrm{b}}$ Departamento de Fitopatologia e Nematologia, ESALQ-USP, CP 9, 13418-900, Piracicaba, Brazil \\ ${ }^{\mathrm{C}}$ EMBRAPA Uva e Vinho, CP 130, 95700-000 Bento Gonçalves, Brazil
}

\section{A R T I C L E I N F O}

\section{Article history:}

Received 12 May 2011

Received in revised form

2 August 2011

Accepted 4 August 2011

\section{Keywords:}

Phyllosticta citricarpa

Epidemiology

Disease management

\begin{abstract}
A B S T R A C T
Guignardia citricarpa, the causal agent of citrus black spot (CBS), forms ascospores and conidia in citrus leaf litter and only conidia on fruit and twigs. The objective of this work was to determine the relative importance of inoculum sources of ascospores and conidia in the progress of CBS under natural conditions in Brazil. A first experiment was conducted in an orchard subdivided into two areas. In one area, fallen leaves were removed and in the other area fallen leaves were maintained. In each area, two treatments were established: 1) CBS symptomatic mature fruit remained on the trees after the new fruit set, and 2) CBS symptomatic mature fruit were harvested before the new fruit set. A second experiment was carried out in a CBS-free experimental orchard where detached symptomatic fruit and leaf litter on the orchard floor and detached symptomatic fruit and dead twigs on the tree canopy were distributed to investigate the spread of disease. In the first experiment disease incidence was similar for all treatments in all years. However, in 2003, in the area without leaf litter (absence of the ascospores source), disease intensity and the rate of progress of disease incidence were higher when there was overlap of mature and young fruit. In the second experiment, only detached symptomatic fruit and dead twigs on the tree canopy were able to spread CBS in two years of the experiment. The distance of disease spread was less than $80 \mathrm{~cm}$ from these inoculum sources. The removal of fallen leaves was not sufficient to completely suppress the disease because of the presence of conidia in fruit and dead twigs. Therefore the reduction of conidia sources should be considered in CBS management in Brazil.
\end{abstract}

(c) 2011 Elsevier Ltd. All rights reserved.

\section{Introduction}

Citrus black spot (CBS), caused by Guignardia citricarpa Kiely anamorph [Phyllosticta citricarpa (McAlp.) van der Aa.], affects all citrus species of commercial value except sour orange (Citrus aurantium L.) and Tahiti lime (Citrus latifolia Osbeck) (Kotzé, 1981; Aguilar-Vildoso et al., 2002; Baldassari et al., 2008). G. citricarpa is a pathogen specific to citrus, and causes lesions on twigs and fruit (Aguilar-Vildoso et al., 2002). Occasionally CBS lesions are also formed on leaves, particularly on lemon trees (Citrus limon L.) (Kotzé, 2000). CBS fruit lesions are limited to the epicarp (Cardoso Filho, 2003) and decrease the value of fruit for the fresh market. CBS

\footnotetext{
* Corresponding author. Tel.: +55 193429 4124; fax: +55 1934294385 .

E-mail address: liamorim@esalq.usp.br (L. Amorim).

1 Present address: Departamento de Produção Vegetal, ESALQ-USP, CP 9, 13418900, Piracicaba, Brazil.
}

does not affect the internal quality of the fruit (Kotzé, 2000). However, high CBS severity may cause premature fruit drop (Kotzé, 2000).

On fruit, CBS symptomatology is diverse. According to Kotzé (2000), three symptoms are associated with the disease. The first symptom is called hard spot, characterized by dark brown lesions surrounding a depressed, round, light brown to gray centre that contains pycnidia. This symptom appears as fruit change colour. The second symptom is false melanose, and is characterized by small black spots distributed over the fruit, sometimes giving rise to a tear-streaked pattern when spore-laden water flows over the fruit. This symptom appears on green fruit, and the lesions do not have fungal fructifications. The third symptom is freckle spot, which is characterized by small red depressed lesions that usually appear at fruit maturation and post-harvest. Pycnida are produced in the freckle spot centre.

During CBS epidemics, G. citricarpa produces sexual and asexual spores. In the sexual phase, pseudothecia with ascospores are 
produced exclusively in decomposing leaves on the orchard floor (McOnie, 1965; Kotzé, 1981). The production and maturation of ascospores are favoured by alternating dry and wet periods, a situation frequently observed during the rainy season (Kotzé, 2000). The active release of ascospores occurs when pseudothecia are moistened after maturity. Ascospores are ejected up to a height of about $1 \mathrm{~cm}$ and are dispersed by air currents (Kiely, 1948; Kotzé, 1963). On the tree surfaces and in the presence of free water for periods longer than $15 \mathrm{~h}$, ascospores infect the host by direct penetration and form a mycelial mass in the sub-cuticular region. The fungus then remains quiescent until the leaves senesce or the fruit begins to ripen (McOnie, 1967; Kotzé, 2000).

In the asexual phase, pycnidia with conidia of $G$. citricarpa are produced in hard spot and freckle spot fruit lesions as well as on leaf litter prior to pseudothecia formation (Kotzé, 2000). When the pycnidia are mature, the conidia covered with a mucilaginous substance emerge from the ostiole. In contact with water, the mucilage is dissolved and the conidia are dispersed by splashing or washed off by rain to nearby susceptible tissues, where new infections may occur (Kotzé, 1981, 2000). The infection and colonization processes of conidia of G. citricarpa are similar to those of ascospores. The incubation period of conidia artificially inoculated fruit with $20-30 \mathrm{~mm}$ in diameter may vary from 55 to 225 days (Baldassari et al., 2009).

Plant diseases whose pathogens simultaneously produce sexual and asexual spores, such as the rubber tree leaf blight (caused by Microcyclus ulei (P. Henn.) v. Arx) and the yellow Sigatoka leaf spot disease (caused by Mycosphaerella musicola Leach) are difficult to control (Bergamin Filho and Amorim, 1996). In these cases, the different propagules have distinct and complementary roles, and under ideal conditions, both propagules can contribute to epidemic development. This enables these pathogens to overcome adverse environmental conditions, which helps to ensure not only their survival but also to increase the disease level in the field (Bergamin Filho and Amorim, 1996). Epidemiological studies on CBS in Australia and South Africa showed that even though both types of inoculum are present in citrus orchards, only the ascospores of G. citricarpa are responsible for the epidemics (Kiely, 1948; Kotzé, 1963). Theoretically, CBS might be controlled by covering the ascospore-releasing leaves on the orchard floor during the critical period of infection. Based on this, one measure of a CBS risk mitigation system applied in areas of Argentina that export lemons is the removal of fallen leaves before the next flowering period (Fogliata et al., 2000). In Brazil, many attempts to control CBS by grass mulching were unsuccessful and at least five fungicide applications are necessary to reduce disease symptoms on fruit (Rossêtto, 2009).

Two independent experiments were carried out with the main objective of determining the relative importance of various inoculum sources in CBS epidemic progress in São Paulo State, Brazil. The first experiment aimed to determine the importance of ascospores in citrus leaf litter on the orchard floor and conidia on attached symptomatic mature fruit as inoculum sources in a naturally infected sweet orange (Citrus sinensis (L.) Osbeck) orchard. The second experiment aimed to assess the importance of leaf litter, detached symptomatic fruit on the canopy and on orchard floor, and dead twigs on the disease spread in a sweet orange orchard free of CBS.

\section{Materials and methods}

\subsection{Experiment 1 - leaf litter and symptomatic fruit as inoculum sources of Guignardia citricarpa in a CBS-affected orchard}

The experiment was performed during two crop seasons (2002 and 2003) in a commercial citrus orchard in São Paulo state with a history of CBS occurrence. A 10.2-ha orchard of 8-year-old sweet orange trees of 'Valencia late', grafted on 'Rangpur' lime (Citrus limonia Osbeck) at $7.5 \mathrm{~m} \times 3.5 \mathrm{~m}$ spacing, was selected. The orchard was divided into two areas of 5.1 ha with 1940 trees each (Fig. 1A). Both areas were exposed to the same environmental conditions and no fungicide was applied in either years.

In Area 1, fallen citrus leaves were maintained on the orchard floor and allowed to decompose naturally during the entire experimental period. In Area 2, fallen citrus leaves were collected monthly by a debris loader (Fig. 1B) and removed from the area. The 30-day interval between leaves removals minimized the probability that ascospores were formed on leaf litter, as this period is shorter than the 40 days required for pseudothecia formation (Kotzé, 1981). The northern portion of Area 1 and the southern portion of Area 2 were chosen for the establishment of the following treatments: 1) mature fruit from the previous year remained on the trees for one month after the new fruit set, so that the conidia produced on the old symptomatic fruit could serve as inoculum for infection of the new fruit, and 2) all the mature fruit from the previous year's crop was harvested before the onset of the new flowering period to avoid overlap of fruit from successive crops. Five plots per treatment were arbitrarily distributed in each subarea and used as replicates. Each plot consisted of seven rows with eight trees per row. Within each plot, disease assessments
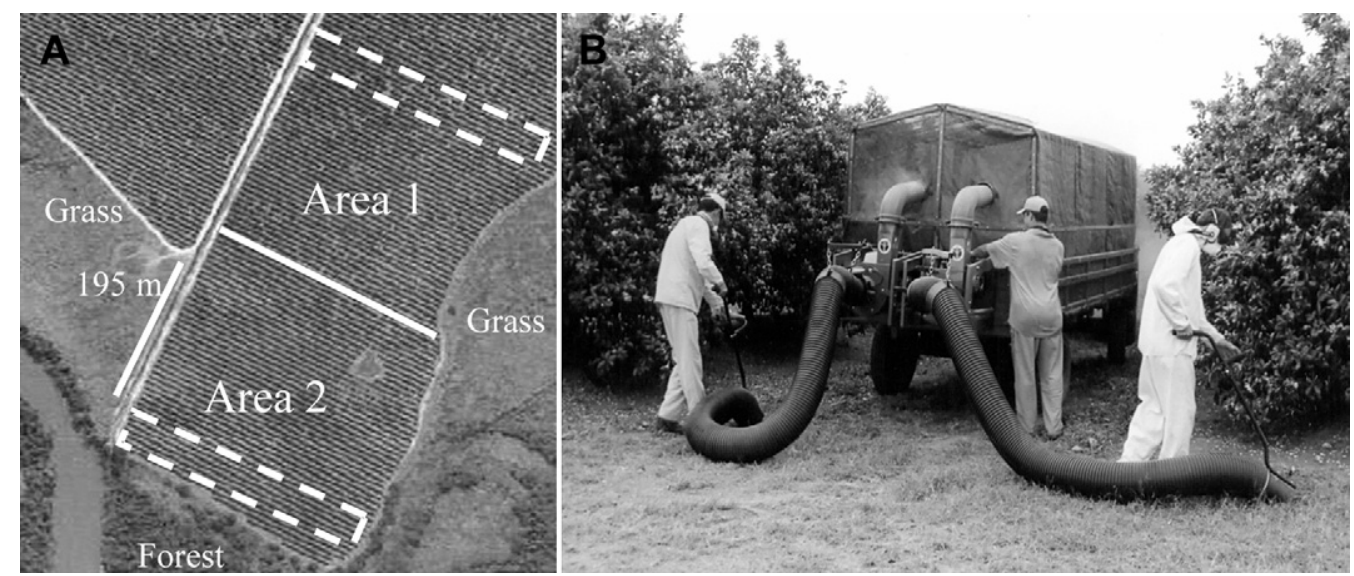

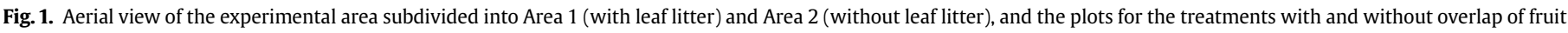
from successive crops (dashed rectangles) (A). Removal of fallen leaves on the orchard floor using a debris loader (B). 
were made on the four central trees of each of the three central rows. The plots from Area 2 were $195 \mathrm{~m}$ apart from Area 1 to avoid possible ascospores influx from Area 1 (Fig. 1A). In the remaining trees of both areas, mature fruit was harvested before the new flowering period.

Prior to initiation of the experiment (2001 harvest) and during the 2002 and 2003 harvests, disease incidence (proportion of symptomatic fruit per tree) and severity (proportion of fruit surface covered with symptoms) were evaluated on 50 arbitrarily selected fruit per tree. Disease severity was evaluated using a modified CBS diagrammatic scale with 12 severity classes $(0.5 ; 1.15 ; 3.0 ; 4.5 ; 9.0$; $15.0 ; 23.0 ; 31.0 ; 45.0 ; 53.0 ; 68.0$; and $84.0 \%$ ), based on the scale of Spósito et al. (2004b). A disease intensity index was calculated based on the distribution of frequency of fruit in the classes of the diagrammatic scale, and its angular transformation $(\omega)$ was subjected to analysis of variance, according to Czermainski (1999). The equation for $\omega$ is: $\omega=\sum_{j=1}^{J} k_{j} \sqrt{p_{j-1, j}}$ arc $\sin \sqrt{f_{j}}$, where $J$ is the number of classes of the diagrammatic scale, $F_{j}$ is the observed frequency in the respective class $j, f_{\mathrm{j}}=\left(F_{j}+F_{j+1}+\ldots+F_{j}\right) /\left(F_{j-1}+F_{j}+F_{j+1}+\ldots+F_{J}\right)$, $j=1, \ldots J$ and $p_{j-1 J}=p_{j}+p_{j+1}+\ldots+p_{J}, j=1, \ldots J$, with the probabilities $p_{j}$ estimated by $F_{j} / 50\left(p_{0 J}=1\right.$ and $\left.p_{1 J}=f_{1}\right)$, and $k_{j}$ is the proportionality coefficient. The mean disease intensity index $(\overline{\mathrm{I}})$ per treatment was calculated using the equation: $\overline{\mathrm{I}}=\sin ^{2} \bar{\omega}$.

The analysis of variance of the disease incidence and $\bar{I}$ for each experimental year was performed according to the completely randomized model. The $F$ test was used for the comparison of the treatments in each area.

In 2003, disease incidence and severity were evaluated during the development of the fruit on the same trees as in 2002. Six monthly assessments were made from March to August. Disease incidence was used for the development of CBS progress curves for each combination of area (Area 1, with, and Area 2, without leaf litter on the orchard floor) and treatment (with and without overlap of fruit from successive crops). The monomolecular model $\left[\left(Y=1-\left(1-y_{0}\right) \cdot \exp (-r . t)\right.\right.$, in which $Y$ is the incidence of the disease, $y_{0}$ is the initial amount of disease incidence, $r$ is the disease progress rate, and $t$ is time] was fitted to disease incidence in 2003 (Campbell and Madden, 1990) by non-linear regression analyses (Quasi-Newton estimation) using the Statistica software (version 6.0, Statsoft, Tulsa, USA). The monomolecular model is usually fitted to CBS incidence progress curves (Spósito et al., 2004a). The initial amount of disease incidence and the disease progress rate of the CBS incidence curves for each treatment within each area were compared by $t$ tests. The mean disease intensity index (I) from each treatment inside each area was compared by ANOVA for all assessments in 2001-2003.

\subsection{Experiment 2 - leaf litter, detached symptomatic fruit, and dead twigs as inoculum sources of Guignardia citricarpa in a CBS- free experimental orchard}

The experiment was carried out in an experimental farm located at least $8 \mathrm{~km}$ from any other citrus trees. The citrus plants were established four years before the beginning of the experiment with certified nursery citrus plants of late 'Natal' sweet orange grafted on 'Rangpur' lime. At the beginning of the experiment, none of the citrus trees at this location showed symptoms of CBS.

The experiment was established in two independent areas; one area to test ascospores, and another area to test conidia as inoculum source. To test ascospores as a source of inoculum, decomposing citrus leaves collected in highly CBS-affected sweet orange groves were applied in four 3.02-ha citrus plots with 1080 trees. Each plot had 24 rows with 45 trees at a spacing of $7.0 \mathrm{~m} \times 4.0 \mathrm{~m}$. Only the central tree of each plot received the treatment which consisted of covering approximately $1.5 \mathrm{~m}^{2}$ of the orchard floor under the tree canopy with an 8-cm deep layer of citrus leaves encaged by a thin wire net (Fig. 2A). The average distance between the leaf litter and the fruits on the canopy was approximately $30 \mathrm{~cm}$. The method described by Whiteside (1967) was used to test conidia as a source of inoculum. Symptomatic oranges and dead citrus twigs collected in highly CBS-affected sweet orange groves were distributed in a 1.46-ha citrus plot with 17 rows containing 35 trees at a spacing of $7.0 \mathrm{~m} \times 3.5 \mathrm{~m}$. Four treatments were applied: 1) five ripe fruit with an average $6 \mathrm{~cm}$ of diameter and more than 10 lesions of hard spot symptom were placed on the floor, around $30 \mathrm{~cm}$ under the fruits on the canopy of the tree (Fig. 2B); 2) five ripe fruit with an average $6 \mathrm{~cm}$ of diameter and more than 10 lesions of hard spot symptom, were attached individually with wire to the canopy of the tree (Fig. 2C); 3) five dead twigs with an average diameter of $0.5 \mathrm{~cm}$ and an average length of $30 \mathrm{~cm}$ were individually wired in the canopy of the tree (Fig. 2D); and 4) trees without any added source of inoculum were used as a control. The experiment had a complete randomised design with ten replicates. A border of four trees in the row and two rows was used for each replication. All treatments were established in October 2005 when set fruit was approximately $1 \mathrm{~cm}$ in diameter. In plots with decomposing citrus leaves as inoculum source, the ascospores release was monitored by a volumetric spore trap (Quest Developments, Brits, South Africa) with a capacity of $20 \mathrm{~L} / \mathrm{h}$ located immediately to the side of the decomposing leaf layer and assessed by the immunolabel method according to Duarte et al. (2005).

CBS incidence was assessed in all trees of the experiment. Disease severity of each symptomatic fruit was estimated using a diagrammatic scale (Spósito et al., 2004b). The position and the distance of each symptomatic tree from the tree where leaf litter was used as source of inoculum as well as the position and the distance of each symptomatic fruit in relation to fruit and twigs used as sources of inoculum were assessed in March, July and September 2006.

Additionally, in September 2007, in the area that received leaf litter as the source of inoculum, ten leaves and five asymptomatic fruit in 30 trees close to the central tree from each plot were collected for detection of $G$. citricarpa and the endophytic Guignardia mangiferae. The 1200 collected leaves were washed with distilled water for $1 \mathrm{~min}$, disinfested with $70 \%$ ethanol for $1 \mathrm{~min}$ and with $1 \%$ sodium hypochlorite for $4 \mathrm{~min}$. The leaves were then washed in $70 \%$ ethanol for $30 \mathrm{~s}$, and finally rinsed with sterile distilled water for $6 \mathrm{~min}$. Leaf pieces of $0.25 \mathrm{~cm}^{2}$ were placed on potato dextrose agar medium. After the mycelium appeared, samples were tested by PCR for G. citricarpa and G. mangiferae (Bonants et al., 2003). The 600 collected fruit samples were immersed in an Ethephon solution (480 ppm) and, after drying, were maintained under continuous light at $20{ }^{\circ} \mathrm{C}$ for 2 weeks to allow for CBS symptom expression (Aguilar-Vildoso et al., 2002).

The numbers of symptomless and symptomatic fruit as well as the maximum distance of symptomless and symptomatic fruit from the inoculum sources for each position were plotted in a radial grid displaying the scale value of the grid lines encircling a central point that represented the inoculum source.

The incidences of symptomatic fruit were parsed into $10-\mathrm{cm}$ frequency categories across all data sets combined for each assessment and inoculum source. The data were then plotted as the frequency of disease incidence by distance from nearest inoculum source and fitted by non-linear regression to the negative exponential model $\left[y=b_{1} \cdot \exp \left(-b_{2} \cdot x\right)\right]$, the inverse power law model $\left[y=b_{1} \cdot x \cdot \exp \left(-b_{2}\right)\right]$, a deterministic version of the half-Cauchy distribution $\left[y=b_{1} /\left(1+\left(b_{2} \cdot x\right)^{2}\right]\right.$, and a generalized gradient model $\left[y=b_{1} \cdot x \cdot \exp \left(-b_{2} \cdot b_{3}\right)\right]$ where $y$ is disease incidence and $x$ is the distance from the nearest inoculum source, in $\mathrm{cm}$, for disease gradient analysis (Madden et al., 2007). 


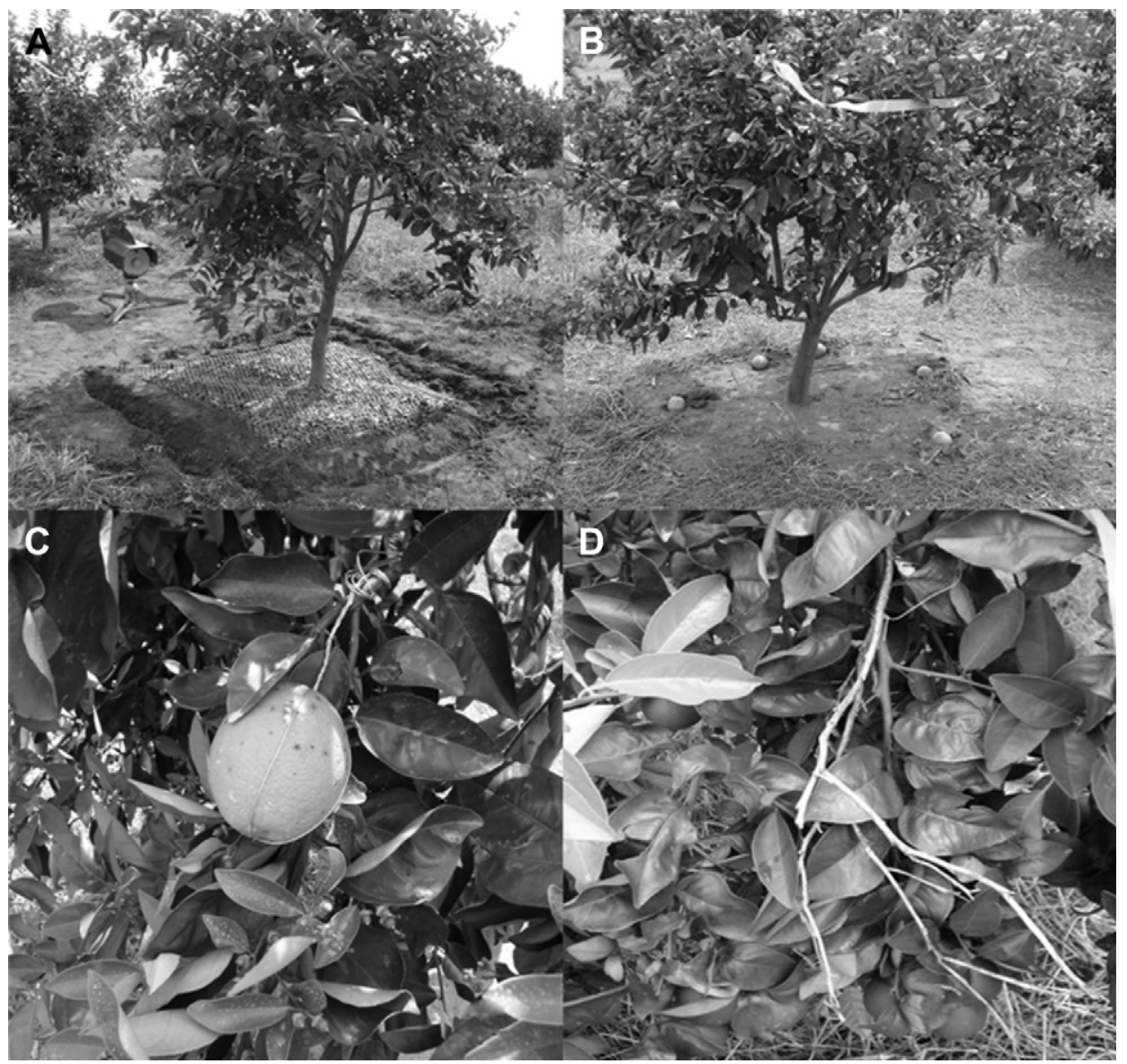

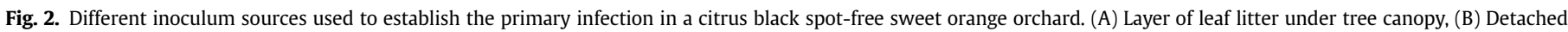
fruit with hard spot symptoms under tree canopy, (C) Detached fruit with hard spot symptoms on the tree canopy, (D) Dead twigs on the tree canopy.

\section{Results}

\subsection{Experiment 1 - leaf litter and symptomatic fruit as inoculum sources of Guignardia citricarpa in a CBS-affected orchard}

The disease incidence and severity assessed in the beginning of the experiment did not show significant differences $(P>0.05)$ between the treatments (with or without overlap of fruit) within each area. The same results were found for disease incidence $(52.2 \%-81.8 \%)$ and disease intensity index (6.9-14.5) assessed in 2001 and 2002. In 2003, CBS incidence increased throughout the year; however in the last assessment, incidence decreased as a result of early drop of severely affected fruit. Therefore, data from this last assessment were not considered for treatment comparisons (Fig. 3). The comparative analysis of CBS progress curves revealed significant $(P<0.01)$ differences in the initial amount of disease incidence and on the rate of disease progress among the different treatments in the area without leaf litter (Table 1). The estimated initial amount of disease incidence for treatment with fruit overlap was higher $(P<0.01)$ than that for treatment without fruit overlap. This result differed from the area with leaf litter, where the estimated initial amount of disease incidence was similar for both treatments (Table 1). The CBS progress rate in the area without leaf litter for treatment with fruit overlap was higher $(P<0.01)$ than that for treatment without fruit overlap.
3.2. Experiment 2 - leaf litter, detached symptomatic fruit, and twigs as inoculum sources of Guignardia citricarpa in a CBS-free experimental orchard

Symptomatic fruit were observed only in plots that had dead twigs and detached fruit with CBS symptoms on the tree canopy as sources of inoculum. The assessment of disease in September 2006 was not used in the analyses because of early drop of symptomatic fruit. Disease severity was different in the two inoculum sources only in March 2006 (Table 2)

Fruit were present in the tree canopy at the maximum distance of $110 \mathrm{~cm}$ from the centre of detached fruit and dead twigs as sources of inoculum. The maximum distance between the centre of the inoculum sources and diseased fruit were $56 \mathrm{~cm}$ for detached symptomatic fruit (Fig. 4A) and $77 \mathrm{~cm}$ for dead twigs (Fig. 4B). Most symptomatic fruit were observed below the source of inoculum and between $225^{\circ}$ and $315^{\circ}$ (Fig. 4). A clear dispersion gradient described by the negative exponential model was observed only when symptomatic fruit were used as source of inoculum. However, for both sources of inoculum $87 \%$ of diseased fruit appeared in the first $30 \mathrm{~cm}$ (Fig. 5).

No symptoms were observed in plots with leaf litter as a source of inoculum in either years (2006 or 2007). However, ascospores from Guignardia spp. were captured in the spore trap from October 2005 to August 2006, ranging from 30 to 325 ascospores/liter/ 


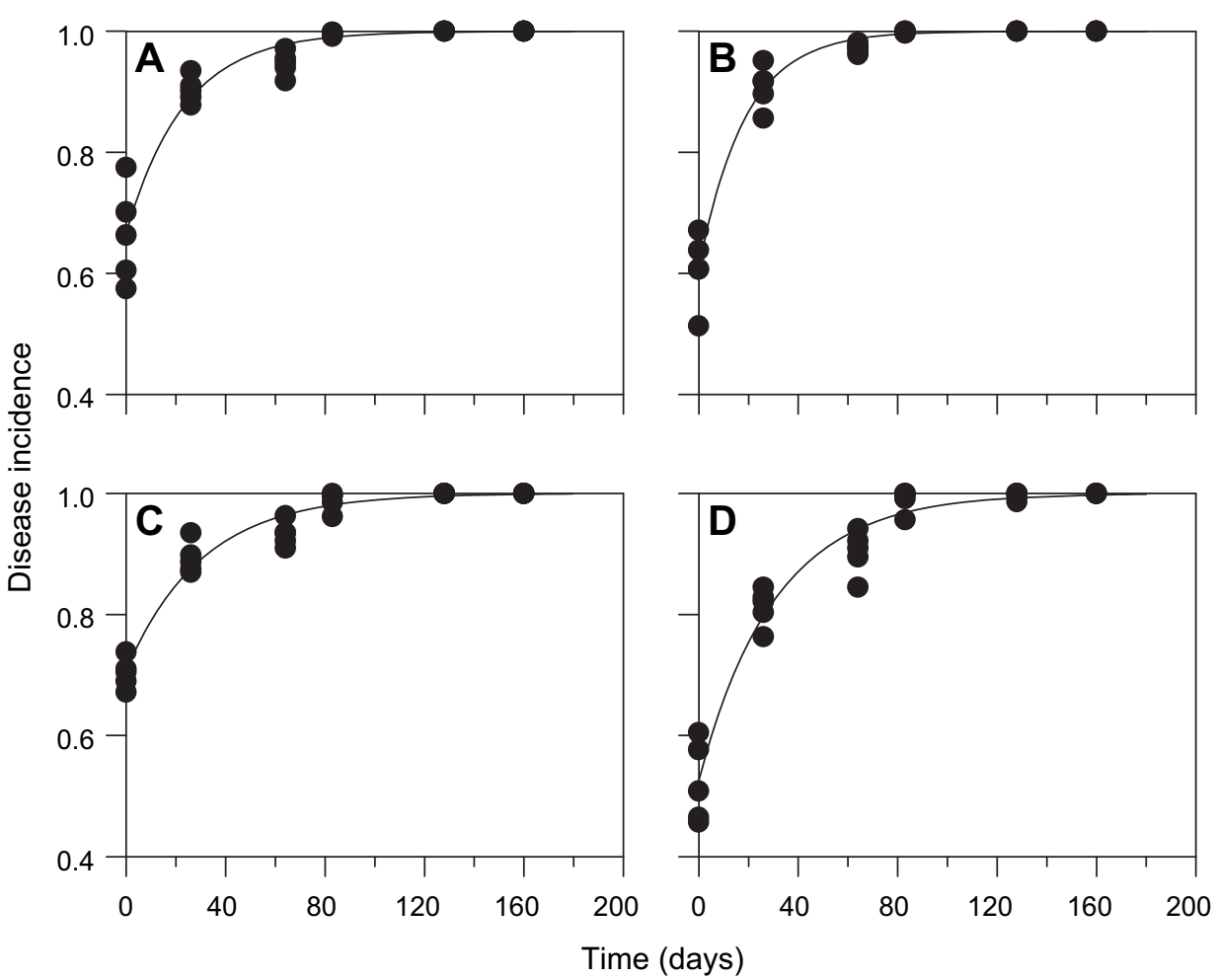

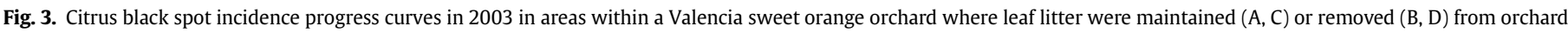
floor and in treatments with (A, B) or without (C, D) overlap of fruit from successive crops.

month. In 2007, G. mangiferae was detected in leaves collected from the trees in the plots that received leaf litter.

\section{Discussion}

In previous works, aggregation of diseased fruit in the trees suggested that splash-dispersed conidia have an important role in CBS epidemics (Spósito et al., 2008). However, the present study is the first evidence that, in addition to ascospores, conidia produced on fruit or twigs in the trees are important inoculum sources of G. citricarpa in Brazil, even if they are dispersed at short distances. The significant differences in CBS intensity between the treatments with and without fruit overlap in the area without leaf litter, after two years demonstrates that conidia formed on fruit played a role in the increase of the disease. This is in contrast with the results of Baldassari et al. (2006), who indicated that conidia formed on fruits

Table 1

Initial amount of disease incidence $\left(y_{0}\right)$, disease progress rate $(r)$, maximum asymptote $\left(b_{1}\right)$, and determination coefficient $\left(R^{2}\right)$ estimated by the monomolecular $\left[Y=1-\left(1-y_{0}\right) \cdot \exp (-r . t)\right]$ model, used to describe the progress of citrus black spot (caused by Guignardia citricarpa) incidence in 2003, in areas within a Valencia sweet orange orchard where leaf litter were maintained or removed from the soil surface and in treatments with or without overlap of fruit from successive crops.

\begin{tabular}{lllll}
\hline Treatment & $y_{0}$ & $r$ & $b_{1}$ & $R^{2}$ \\
\hline Area with leaf litter & & & & \\
+Fruit overlap & $0.667 \mathrm{a}$ & $0.042 \mathrm{a}$ & 1 & 0.92 \\
-Fruit overlap & $0.708 \mathrm{a}$ & $0.033 \mathrm{a}$ & 1 & 0.96 \\
Area without leaf litter & & & & \\
+Fruit overlap & $0.608 \mathrm{a}$ & $0.054 \mathrm{a}$ & 1 & 0.97 \\
-Fruit overlap & $0.526 \mathrm{~b}$ & $0.032 \mathrm{~b}$ & 1 & 0.96 \\
\hline
\end{tabular}

Values followed by the same letter within each column do not differ significantly by the $t$ test $(P>0.01)$ from the previous crop did not increased CBS severity on the fruits of the subsequent harvest period. Although initial inoculum $\left(y_{0}\right)$ and disease progress rate $(r)$ were significantly reduced, disease incidence in the area without leaf litter and no overlap of fruit, was $100 \%$ after 120 days. This result was probably due to the inoculum produced on dead twigs. Results from the experiment that tested different sources of inoculum proved that dead twigs are sources of G. citricarpa inoculum. The possibility that ascospore contamination occurred between the areas is unlikely because the areas were $195 \mathrm{~m}$ apart and the disease has a spatial aggregation pattern of approximately $25 \mathrm{~m}$ (Spósito et al., 2007). This aggregation indicates that ascospore dispersion occurs at similar distances. The distance of disease spread when the inoculum is conidia produced on dead twigs or symptomatic fruit is limited to $80 \mathrm{~cm}$. Conidia of G. citricarpa are produced in pycnidia and are surrounded by mucilage. When wet, the mucilage dissolves and the spore suspension is dispersed by splashing raindrops or by the thin film of water that runs over the fruit (Kotzé, 2000). Fungi with spores

Table 2

Incidence of symptomatic fruit (percentage of fruit with at least one spot) and disease severity (percentage of fruit surface covered with symptoms) at different assessment time.

\begin{tabular}{llc}
\hline Source of inoculum & March, 2006 & July, 2006 \\
\hline Disease incidence (\%) & & \\
Symptomatic fruit & $43.5 \mathrm{a}$ & $90.0 \mathrm{a}$ \\
Dead branches & $32.9 \mathrm{a}$ & $85.5 \mathrm{a}$ \\
Disease severity (\%) & & \\
Symptomatic fruit & $21.9 \mathrm{a}$ & $12.7 \mathrm{a}$ \\
Dead branches & $8.4 \mathrm{~b}$ & $11.2 \mathrm{a}$ \\
\hline
\end{tabular}

Values followed by the same letter within each column do not differ significantly by Tukey test $(P>0.01)$. 
A

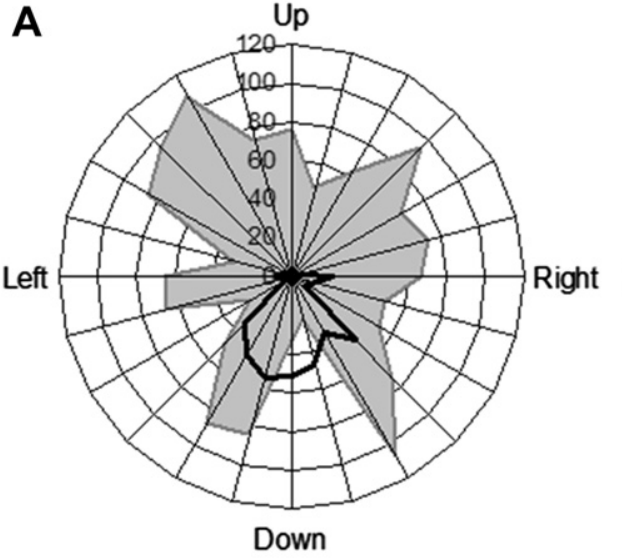

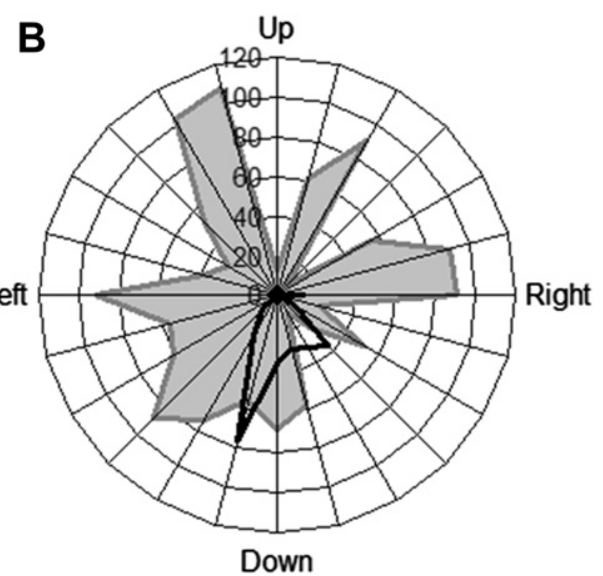

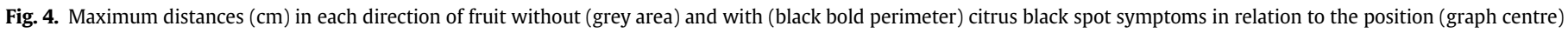
of symptomatic fruit (A) and dead twigs (B) as Guignardia citricarpa conidia inoculum sources. Each graph represents the total amount of fruit in each treatment.

covered by mucilage are dispersed over short distances by rain (Fitt et al., 1989). Thus, conidia contribute to disease increase and spread inside the tree or to its neighbors.

In this study, symptomatic fruit placed underneath the canopy as source of inoculum did not contribute to disease spread. No fruit above the inoculum sources, independently if the sources were on the ground or in the tree, was infected in the experimental plots. These results are in agreement with previous studies conducted in Zimbabwe, where it was concluded that the dispersal of conidia was almost entirely in a downward direction (Whiteside, 1967). Truter et al. (2007) also demonstrated that conidia from fruit on the orchard floor were not able to infect the nearby leaf litter. Under natural epidemics in Brazil, CBS incidence and severity are higher in the bottom of the canopy, compared to the top (Spósito et al., 2008). However, according to Fitt et al. (1989), without wind, a few splash-borne spores can be spread more than $50 \mathrm{~cm}$ above the source. This finding suggests that, in Brazil, fruit dropped on the ground are not likely to be an important source of inoculum in field epidemics. However, this should be further confirmed by conducting experiments in mature orchards with lower canopy skirts.

Ascospores are considered the main source of inoculum of G. citricarpa, but in our study, plots exposed to infected leaf litter did no develop CBS symptoms. The spore sampler detected ascospores in the experimental site, but in much lower number than reported in orchards where the disease is endemic (Reis et al., 2006). This may be a consequence of the low density of infected leaf litter used, which only covered $1.5 \mathrm{~m}^{2}$ of the soil surface in each 3-ha plot. Kotzé (1981) indicated that CBS is more severe on old trees than on young trees, which may not show symptoms even under epidemic conditions. Thus, the young age of the trees ( $4 \mathrm{yr}$ ) used in the experiment may also influenced the results.

The higher initial amount of disease in the CBS incidence curve where leaf litter was the only source of inoculum compared to fruit as the only source of inoculum, was related to the ascospores produced on leaf litter and to the fact that the distances reached by the ascospores were greater than those by the conidia. Thus, a greater amount of fruit is reached by ascospores in the beginning of the epidemic, resulting in a higher incidence of the disease. The greatest distances reached by ascospores in relation to the distances reached by conidia explain the similarity of initial amount of disease incidence in the treatments with and without overlap of fruit in the area where leaf litter was used as inoculum. The rates of progress of CBS incidence were higher when there was overlap of fruit. In fact, the lesions that originated from conidia are aggregated on the fruit generating higher disease severity (Spósito et al., 2008). This higher severity causes the production of a greater amount of inoculum, which consequently increases the epidemic rate. The final levels of disease severity were also higher in the treatments where there was fruit overlap (data not shown).

In Brazil, the use of mulching and leaf litter elimination in affected orchards were evaluated as disease control measures for CBS (Rossêtto, 2009). However, these cultural practices are insufficient to suppress the disease. In addition to the above mentioned

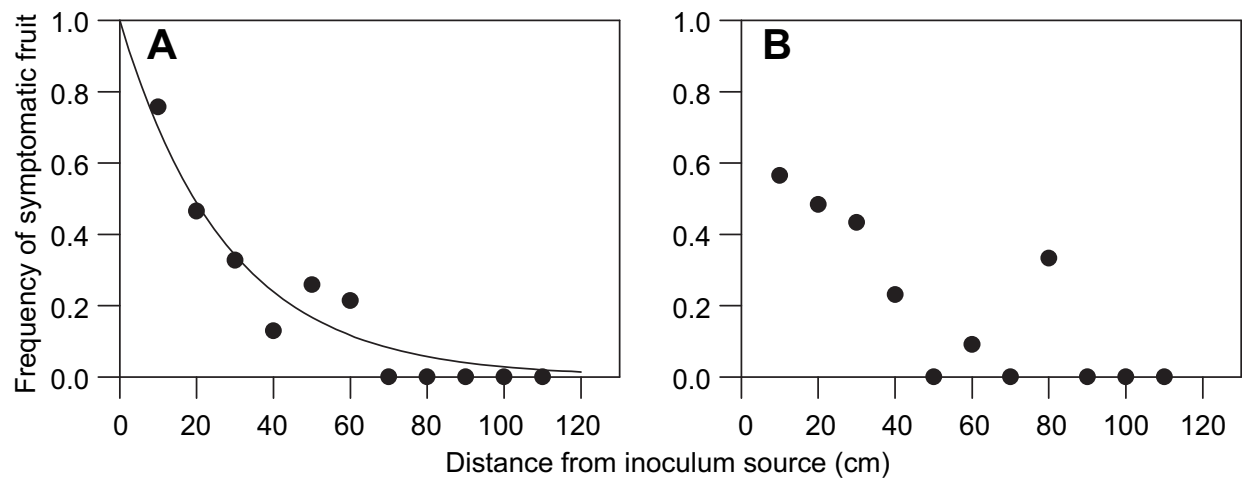

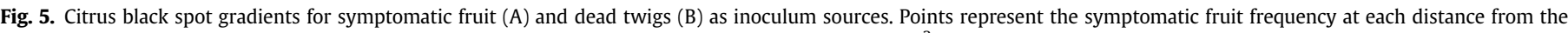
inoculum source. The curve was generated using the negative exponential model $\left[y=\exp (-0.036 \cdot x), R^{2}=0.88\right]$. 
techniques, disease management must consider reducing sources of $G$. citricarpa conidia.

Our results differ from studies conducted in Australia and South Africa where CBS behaves as a monocyclic disease due to infections from ascospores (Kiely, 1948; Kotzé, 1963, 2000; McOnie, 1964, 1965). This behavior can be attributed to four characteristics of South Africa and Australia: i) uniform flowering and fruiting due to the use of drip irrigation and cooler temperatures that lead to few off-season fruit (Kotzé, 1981), ii) period of fruit infection restricted to four months, when the rain period occurs (Kotzé, 1981, 1963; McOnie, 1964), iii) no overlapping of old and new fruits, because complete harvest occurs before the new flowering period (Kotzé, 1981), and iv) differences in the frequency and type of pruning (mechanical vs. manual) that might influence the amount of dead twigs in the canopy. In São Paulo State there are longer periods of infection than in South Africa and Australia, associated with successive and irregular bloom in the cultivated varieties. In the late varieties of sweet orange, such as 'Valencia' and 'Natal', the fruit remain susceptible for at least 6 months (Baldassari et al., 2009). The presence of susceptible fruit for a long period of time and favorable weather conditions for infection increase the importance of conidia in the CBS epidemic.

\section{Acknowledgements}

We are grateful to FAPESP (Project 2007/53419-8) and CNPq (author's scholarships) for the financial support of this work.

\section{References}

Aguilar-Vildoso, C.I., Ribeiro, J.G.B., Feichtenberger, E., de Goes, A., Spósito, M.B., 2002. Manual Técnico de Procedimentos da Mancha Preta dos Citros. MAPA/ SDA/DDIV, Brasília.

Baldassari, R.B., Reis, R.F., Goes, A., 2006. Susceptibility of fruits of the 'Valência' and 'Natal' sweet orange varieties to Guignardia citricarpa and the influence of the coexistence of healthy and symptomatic fruits. Fitopatologia Brasileira 31, $337-341$.

Baldassari, R.B., Wickert, E., de Goes, A., 2008. Pathogenicity, colony morphology and diversity of isolates of Guignardia citricarpa and G. mangiferae isolated from Citrus spp. Eur. J. Plant Pathol. 120, 103-110.

Baldassari, R.B., Reis, R.F., de Goes, A., 2009. A new method for inoculation of fruit with Guignardia citricarpa, the causal agent of citrus black spot. Eur. J. Plant Pathol. 123, 1-4.

Bergamin Filho, A., Amorim, L., 1996. Doenças de plantas tropicais: epidemiologia e controle econômico. Ceres, São Paulo, Brazil.

Bonants, P.J.M., Carroll, G.C., de Weerdt, M., van Brouwershaven, I.R., Baayen, R.P., 2003. Development and validation of a fast PCR-based detection method for pathogenic isolates of the citrus black spot fungus, Guignardia citricarpa. Eur. J. Plant Pathol. 109, 503-513.
Campbell, C.L., Madden, L.V., 1990. Introduction to Plant Disease Epidemiology. Wiley, New York, USA.

Czermainski, A.B.C., 1999. Generalização de um índice de intensidade de infecção em experimentos de avaliação de doenças em plantas. Pesq. agropec. Bras 34, 1545-1556.

Duarte, K.M., Spósito, M.B., Gomes, L.H., Romano, T.M., Souza, E.R., Wulff, N.A., Amorim, L., 2005. Imunodetecção de Guignardia citricarpa em armadilhas caçaesporos. Fitopatol. Bras 30, 124.

Cardoso Filho, J.A., 2003. Efeito de extratos de albedo de laranja (Citrus sinensis) dos indutores de resistência ácido salicílico, acilbenzolar-s-metil e Saccharomyces cerevisiae no controle de Phyllosticta citricarpa (teleomorfo: Guignardia citricarpa). Piracicaba, Brazil: Escola Superior de Agricultura "Luiz de Queiroz", Universidade de São Paulo, PhD thesis.

Fitt, B.D.L., McCartney, H.A., Walklate, P.J., 1989. The role of rain in dispersal of pathogen inoculum. Annu. Rev. Phytopathol. 27, 241-270.

Fogliata, G.M., Canton, N.V., Ploper, L.D., 2000. Análisis de laboratório para certificación de fruta cítrica del NOA con destino a EE.UU. Avance Agroindustrial EEAOC, 4-7.

Kiely, T.B., 1948. Preliminary studies on Guignardia citricarpa spp.: the ascigerous stage of Phoma citricarpa and its relation to black spot of citrus. Proc. Linn. Soc. N. S. W 93, 249-292.

Kotzé, J.M., 1963. Studies on the black spot disease of citrus caused by Guignardia citricarpa Kiely with particular reference to its epiphytology and control at Lebata. Pretoria, South Africa: University of Pretoria, PhD thesis.

Kotzé, J.M., 1981. Epidemiology and control of citrus black spot in South Africa. Plant Dis. 65, 945-950.

Kotzé, J.M., 2000. Black spot. In: Timmer, L.W., Garnsey, S.M., Graham, J.H. (Eds.) Compendium of Citrus Diseases. APS Press, St. Paul, USA, pp. 23-25.

Madden, L.V., Hughes, G., van den Bosh, F., 2007. The Study of Plant Disease Epidemics. APS Press, Saint Paul, USA.

McOnie, K.C., 1964. Source of inoculum of Guignardia citricarpa, the citrus black spot pathogen. Phytopathology 54, 64-67.

McOnie, K.C., 1965. Source of infection for black spot of citrus. South Afr. Citrus J., 5-9.

McOnie, K.C., 1967. Germination and infection of citrus by ascospores of Guignardia citricarpa in relation to control of black spot. Phytopathology 57, 743-746.

Reis, R.F.D., Timmer, L.W., Goes, A., 2006. Effect of temperature, leaf wetness and rainfall on the production of Guignardia citricarpa ascospores and on black spot severity on sweet orange. Fitopatologia Brasileira 31, 29-34.

Rossêtto, M.P., 2009. Resistência varietal e manejo de mancha preta dos citros. Campinas, Brazil, Instituto Agronômico de Campinas. MSc Dissertation.

Spósito, M.B., Bassanezi, R.B., Amorim, L., 2004a. Resistência à mancha preta dos citros avaliada por curvas de progresso da doença. Fitopatol. Bras 29, 532-537.

Spósito, M.B., Amorim, L., Belasque Jr., J., Bassanezi, R.B., Aquino, R., 2004b. Elaboração e validação de escala diagramática para avaliação da severidade da mancha preta em frutos cítricos. Fitopatol. Bras 29, 81-85.

Spósito, M.B., Amorim, L., Ribeiro Jr., P.J., Bassanezi, R.B., Krainski, E.T., 2007. Spatial pattern of trees affected by black spot in citrus groves in Brazil. Plant Dis. 91, $36-40$.

Spósito, M.B., Amorim, L., Bassanezi, R.B., Bergamin Filho, A., Hau, B., 2008. Spatial pattern of black spot incidence within citrus trees related to disease severity and pathogen dispersal. Plant Pathol. 57, 103-108.

Truter, M., Labuschagne, P.M., Kotzé, J.M., Meyer, L., Korsten, L., 2007. Failure of Phyllosticta citricarpa pycnidiospores to infect Eureka lemon leaf litter. Australasian. Plant. Pathol. 36, 87-93.

Whiteside, J.O., 1967. Sources of inoculum of the black spot fungus, Guignardia citricarpa, in infected Rhodesian citrus orchards. Rhodesia, Zambia Malawi J. Agric. Res. 5, 171-177. 